\title{
Using and Side-effects of Propylene Glycol in Animals
}

\author{
Bulent Elitok* \\ Department of Internal Medicine, Faculty of Veterinary Medicine, Afyon Kocatepe University, Turkey
}

*Corresponding author: Bulent Elitok, Department of Internal Medicine, Faculty of Veterinary Medicine, Afyon Kocatepe University, Turkey, Tel: +902722281092; E-mail: elitok1969@hotmail.com

Received date: April 10, 2018; Accepted date: April 16, 2018; Published date: April 23, 2018

Copyright: (C) 2018 Bulent E. This is an open-access article distributed under the terms of the Creative Commons Attribution License, which permits unrestricted use, distribution, and reproduction in any medium, provided the original author and source are credited.

Citation: Bulent E (2018) Using and Side-effects of Propylene Glycol in Animals. J Contracept Stud Vol.3 No.2:13.

\section{Abstract}

Propylene glycol is a substance widely used in the cattle industry for a long time, especially to healing negative energy balance. However, large amounts of propylene glycol may have some side-effects. The objective of this review was to describe to using of propylene glycol and possible side effects in the adult calf.

\section{Keywords}

Propylene glycol; Animal use; Side-effects

\section{Introduction}

Propylene glycol (PG) has been used in the treatment of ketosis since the 1950s [1] and is still used today [2,3]. In cows after calving very often there is a shortage of energy, a decrease in blood glucose levels and the activation of fatty reserves, which leads to the initiation of the synthesis of harmful ketones. This implies the risk of ketosis in dairy cows in the first stage of lactation [4,5]. It has been reported that orally given PG reduces the propionate ratio of acetate to acetaminophen, while increasing conversion of ruminal PG to propionate, and aid in the closure of energy deficit in cattle [6]. On the other hand, it has been scientifically proven that PG provides substrates for both gluconeogenesis and induces insulin resistance in peripheral tissues to conserve glucose for milk synthesis [7]. After its ingestion, PPG escapes the ruminal fermentation and is metabolized by the liver into glucose through the lactaldehyde pathway and subsequent oxidation to lactate [8]. Some researchers $[9,10]$ that reported a nonsignificant effect of PG supplementation on milk yield, Generally, but for cows in early lactation PG tends to increase milk yield and reduce milk fat percentage, while milk protein percentage is unchanged [11]. Mc Art et al. [12] claim that intensive detection of subclinical ketosis, followed by treatment of positive cows with oral PG decreased the risk of developing a DA.
Recently, PG has been the most carefully studied glucogenic supplements, and some researchers [13] mention that antibacterial and antifungal effects may be present. Thorgeirsdottir et al. [14] reported that PG increased antiviral efficacy in combination with antiviral drugs at different concentrations. Nalawade et al. [15] claimed that PG had bacteriocidal effects on many bacteria, especially E. coli. The same investigators have shown that there is no effect on Staphlococcus aures. Khaw and Panosian et al. [16] reported that an increase in the activity of antiprotozoal drugs used in combination with PG.

Although PG is generally recognized as safe at regulated concentrations, when propylene glycol ingested at toxic doses can cause central nervous system depression, neuro degeneration and lactic acidosis [17]. PG is an approved food additive for dog and sugar glider food under the category of animal feed and is generally recognized as safe for dogs, with an LD50 of $9 \mathrm{~mL} / \mathrm{kg}$. The LD50 is higher for most laboratory animals $(20 \mathrm{~mL} / \mathrm{kg})$. However, it is prohibited for use in food for cats due to links to Heinz body anemia [18].

The side effects of PG when allocated to cows are poorly described in the literature [11]. Although propylene glycol can prevent and treat ketosis in dairy cows, large doses (>500 g/ day) can harm cattle like other herbivores. Symptoms when such doses are fed include depression, ataxia, and excessive salivation, as well as abnormal, malodorous, and foul breath and feces [19]. Moreover, it has also been reported that high doses of these carbohydrate precursors may lead to diarrhea in cattle $[3,20,21]$.

\section{References}

1. Johnson RB (1954) The treatment of ketosis with glycerol and propylene glycol. Cornell Vet 44: 6-21.

2. Bahaa AO, Murphy MR, Morin DE, Spahr SL, Drackley JK, et al. (1997) Induction of ketosis by feed restriction and treatment of ketosis with glucose or propylene glycol. J Dairy Sci 80:166-171.

3. McClanahan S, Hunter J, Murphy M, Valberg S (1998) Propylene glycol toxicosis in a mare. Vet Hum Toxicol 40: 294-296.

4. Włodarczyk R, Budvytis M (2011) Veterinary Life 86: 771-776.

5. Schneider IM, Dobner B, Neubert R, Wohlrab W (1996) Evaluation of drug penetration into human skin ex vivo using 
branched fatty acids and propylene glycol. Int J Pharm 145:187-196.

6. Grummer RG, Winkler JC, Bertics SJ, Studer VA (1994) Effect of propylene glycol dosage during feed restriction on metabolites in blood of prepartum Holstein heifers. J Dairy Sci 77: 3618-3623.

7. Kristensen N, Raun B (2007) Ruminal and intermediary metabolism of propylene glycol in lactating Holstein cows. J Dairy Sci 90: 4707-4717.

8. Miller ON, Bazzano G (1965) Propanediol metabolism and its relation to lactic acid metabolism. Ann N Y Acad Sci.

9. Studer VA, Grummer RR, Bertics SJ, Reynolds CK (1993) Effect of prepartum propylene glycol administration on periparturient fatty liver in dairy cows. J Dairy Sci 76: 2931-2939.

10. Formigoni A, Cornil MC, Prandi A, Mordenti A, Rossi A, et al. (1996) Effect of propylene glycol supplementation around parturition on milk yield, reproduction performance and some hormonal and metabolic characteristics in dairy cows. J Dairy Res 63: 11-24.

11. Nielsen NI, Ingvartsen KL (2004) Propylene glycol for dairy cows: A review of the metabolism of propylene glycol and its effects on physiological parameters, feed intake, milk production and risk of ketosis. Anim Feed Sci Technol 115: 191-213.

12. McArt JA, Nydam DV, Oetzel GR (2012) A field trial on the effect of propylene glycol on displaced abomasum, removal from herd, and reproduction in fresh cows diagnosed with subclinical ketosis. J Dairy Sci 95: 2505-2512.
13. Robinson E, Sprayberry KA (2009) Current Therapy in Equine Medicine. Elsevier Health Sciences, USA.

14. Thorgeirsdotthr TO, Thormar H, Kristmundsdottir T (2003) Effects of polysorbates on antiviral and antibacterial activity of mono glyceride in pharmaceutical formulations. Pharmazie 58: 286-287.

15. Nalawade TM, Bhat K, Sogi SHP (2015) Bactericidal activity of propylene glycol, glycerine, polyethylene glycol 400, and polyethylene glycol 1000 against selected microorganisms. J Int Soc Prev Community Dent 5: 114-119.

16. Khaw M, Panosian CB (1995) Human Antiprotozoal Therapy: Past, Present, and Future. Clin Microbiol Rev 8: 427-439.

17. Lau K, Swiney BS, Reeves N, Noguchi KK, Farber NB (2012) Propylene Glycol produces excessive apoptosis in the developing mouse brain, alone and in combination with Phenobarbital. Pediatr Res 71: 54-62.

18. Peterson M, Talcott PA (2006) Small animal toxicology. Saunders Elsevier. St. Louis. 997.

19. Trabue S, Scoggın K, Tjandrakusuma S, Rasmussen MA, Reilly PJ (2007) Ruminal Fermentation of Propylene Glycol and Glycerol. J Agric Food Chem 55: 7043-7051.

20. Sabbioni A, Superchi P, Bonomi A, Taglietti P (1999) The use of propylene glycol in veal calf feeding. ASPA Congress 13: 351-353.

21. FDA. Subchapter E-Animal Drugs, Feeds, and Related Products; Propylene glycol. Code of Federal Regulations. 582:1666. 